\title{
Multiresistensi dan Akumulasi Acinetobacter sp. IrC2 Terhadap Logam Berat
}

\author{
WAHYU IRAWATI ${ }^{1, *}$, AARON HASTHOSAPUTRO ${ }^{2}$, LUCIA KUSUMAWATI ${ }^{3}$ \\ 1Program Studi Pendidikan Biologi, Fakultas Keguruan dan Ilmu Pendidikan, Universitas Pelita Harapan, Tangerang \\ ${ }^{2} J u r u s a n$ Biologi, Fakultas Sains dan Matematika, Universitas Pelita Harapan, Tangerang \\ 3International University Liaison Indonesia, Department of Food Technology IULI-Eco Campus, Tangerang
}

Diterima: 4 Juni 2020 - Disetujui: 20 Agustus 2020

(C) 2020 Jurusan Biologi FMIPA Universitas Cenderawasih

\begin{abstract}
The increasing industrial activity in Indonesia, that is not equipped with appropriate waste treatment, has caused an increase of heavy metal contaminants in water bodies. Heavy metals contamination such as copper $(\mathrm{Cu})$, mercury $(\mathrm{Hg})$, cadmium $(\mathrm{Cd})$, and lead $(\mathrm{Pb})$ contamination in water bodies have endangered aquatic life and public health. For this reason, it is urgently important to lower down the concentration of heavy metal pollutants in the water bodies surrounding industrial areas. Compared to chemical remediation, bioremediation of heavy metal by using indigenous bacteria is more effective and economical, since it can be applied in situ directly and be used repeatedly. Acinetobacter sp. $\operatorname{IrC} 2$, used in this study, is Indonesian indigenous bacteria isolated from the industrial waste treatment facility in Rungkut, Surabaya. This study aims, firstly, to investigate the heavy metal multiresistance of Acinetobacter sp. IrC2 against mercury, cadmium, and lead. Secondly, this study intends to examine its bioaccumulation capacity for single and heavy metal alloys. The heavy metal multiresistance test was carried out by measuring the minimum heavy metal concentrations that inhibit bacterial growth (Minimum Inhibitory Concentration/MIC). The bioaccumulation capacity was measured using an atomic absorption spectrophotometer (AAS). It is shown that Acinetobacter sp. IrC2 has high multiresistance to mercury, cadmium, and lead with MIC values of $12 \mathrm{mM}, 8 \mathrm{mM}$, and $18 \mathrm{mM}$, respectively. Furthermore, it is also resistant to heavy metal mixture of $4.5 \mathrm{mM}$. The mechanism of bacterial resistance in response to heavy metal toxicity, in general, is by accumulating heavy metals in the cells. The highest amount of accumulated heavy metals identified, from bacteria grown in the medium contains a mixture of heavy metals, were $0.023 \mathrm{mg}, 0.084 \mathrm{mg}, 0.684 \mathrm{mg}$, and 1.476 mg per gram of cell dry weight for copper, mercury, cadmium and lead respectively. In conclusion, Acinetobacter $\mathrm{sp}$. IrC2 is a promising heavy metal bioremediation agent due to its heavy metal multiresistance and accumulator characteristics.
\end{abstract}

Key words: Acinetobacter sp. IrC2; cadmium; copper; lead; merkuri

\section{PENDAHULUAN}

Kasus pencemaran logam berat akibat buangan limbah merupakan masalah serius yang banyak terjadi di Indonesia. Kadar logam berat

* Alamat korespondensi:

PS. Fakultas Keguruan Ilmu Pendidikan, Universitas

Pelita Harapan, Tangerang.

E-mail: w.irawati3@gmail.com. yang berlebihan dapat mengganggu sistem homeostatis, menghambat pertumbuhan, memicu mutasi gen, mendenaturasi protein, menginduksi zat karsinogen dan berujung pada kematian (Banvalvi, 2011). Pencemaran logam berat mengancam kehidupan organisme karena bersifat persisten yaitu tidak dapat terdegradasi sehingga keberadaannya tetap ada di lingkungan. Logam berat yang paling toksik di lingkungan adalah tembaga, seng, timbal, cadmium, nikel, merkuri (Dash et al., 2016) sehingga diperlukan metode 
pengolahan limbah yang dapat menyisihkan logam berat dari lingkungan.

Metode pengolahan limbah secara konvensional seperti pengendapan kimia, adsorpsi karbon, pertukaran ion, ekstraksi larutan, dan pemisahan membran merupakam metode yang sering digunakan tetapi mempunyai banyak kelemahan, yaitu mahal, membutuhkan banyak energi, dan dapat menghasilkan senyawa lain yang berbahaya. Saat ini pengolahan limbah lebih diarahkan pada potensi bakteri dalam menyisihkan logam berat dari lingkungan atau disebut dengan bioremediasi. Bioremediasi logam berat menggunakan bakteri banyak mendapat perhatian karena memiliki nilai kebaharuan dan berpotensi untuk diterapkan dalam industri (Zaki \& Farag, 2010). Bioremediasi merupakan teknologi pengolahan limbah dengan memanfaatkan sistem biologi untuk mengkatalisis biodegradasi atau transformasi berbagai senyawa toksik menjadi bentuk yang kurang toksik. Proses bioremediasi ini berlangsung secara alami dengan memanfaatkan kemampuan intrinsik bakteri untuk membersihkan lingkungan (Saranraj \& Stella, 2012).

Beberapa bakteri mengembangkan mekanisme adaptasi ketika dihadapkan dengan logam toksik dalam periode panjang dan menyeleksinya dengan membentuk bakteri yang resisten. Bakteri mengembangkan mekanisme resistensi dalam kondisi stres dengan cara mengeluarkan logam dari sel, transformasi menjadi senyawa yang kurang toksik, maupun akumulasi yang dapat dimanfaatkan untuk proses bioremediasi (Williams et al., 2012).

Acinetobacter adalah genus bakteri yang selalu ditemukan di lingkungan dibandingkan dengan genus bakteri lain. Acinetobacter dikenal sebagai genus bakteri yang dapat bertahan hidup di berbagai belahan atmosfir dan dalam kondisi lingkungan yang beragam. Acinetobacter sp. merupakan agen bioteknologi yang penting dan digunakan secara luas untuk menghasilkan enzim dan makromolekul lain, serta berperan mendegradasi senyawa yang membandel (Chan et al., 2011). Acinetobacter merupakan bakteri yang secara umum sering digunakan dalam mekanisme bioremediasi karena mempunyai kemampuan melakukan biosorbsi logam berat (Mendez et al., 2017). Williams et al. (2016) mengatakan bahwa Acinetobacter sp. mempunyai resistensi terhadap tembaga sehingga dapat beradaptasi dalam menanggapi tembaga konsentrasi tinggi. Acinetobacter sp. IrC2 merupakan bakteri resisten tembaga yang dapat mengakumulasi tembaga sebagai mekanisme resistensi dalam menanggapi tembaga konsentrasi tinggi (Irawati et al., 2012). Penelitian ini bertujuan untuk menguji sifat multiresistensi dan kemampuan akumulasi Acinetobacter sp. IrC2 terhadap logam berat lain yaitu merkuri, kadmium, dan timbal serta campuran logam berat tersebut.

\section{METODE PENELITIAN}

\section{Galur Bakteri dan Medium Pertumbuhan}

Acinetobacter sp. IrC2 merupakan bakteri resisten tembaga dengan nomor aksesi JX009134 (Irawati et al., 2012). Medium yang digunakan adalah medium Luria Bertani (LB) dengan penambahan logam berat pada konsentrasi tertentu. Stok logam berat tembaga, merkuri, kadmium, dan timbal, masing-masing yang digunakan adalah $1 \mathrm{M} \mathrm{CuSO}_{4} ; 0.25 \mathrm{M} \mathrm{HgCl}_{2} ; 1 \mathrm{M}$ $\mathrm{Cd}\left(\mathrm{NO}_{3}\right)_{2}$ dan $1 \mathrm{M} \quad \mathrm{Pb}\left(\mathrm{NO}_{3}\right)_{2}$. Logam berat dimasukkan ke dalam medium LB yang telah disterilkan dengan otoklaf pada suhu $121^{\circ} \mathrm{C}$ selama 21 menit.

\section{Uji Resistensi}

Resistensi Acinetobacter sp. IrC2 diukur berdasarkan nilai Minimum Inhibitory Concentration (MIC) yaitu konsentrasi logam berat tertinggi yang dapat menghambat pertumbuhan bakteri. Resistensi bakteri diuji resistensinya terhadap masing-masing logam berat merkuri, kadmium, timbal serta campuran logam berat tembaga, merkuri, kadmium, dan timbal. Satu ose biakan agar miring Acinetobacter sp. IrC2 diinokulasikan ke dalam masing-masing medium agar yang mengandung logam berat dengan konsentrasi tertentu kemudian diinkubasikan pada suhu 37 ${ }^{\circ} \mathrm{C}$. Pertumbuhan koloni bakteri diamati selama 
masa inkubasi 3 hari untuk menentukan resistensi bakteri. Pengujian resistensi terhadap bakteri dilakukan dengan meningkatkan konsentrasi logam berat tersebut hingga bakteri tidak menunjukkan adanya pertumbuhan (Irawati et al., 2019).

\section{Akumulasi Logam Berat}

Kultur Acinetobacter sp. IrC2 sebanyak $200 \mu \mathrm{l}$ $(\mathrm{OD}=0,9)$ dimasukkan ke dalam $20 \mathrm{ml} \mathrm{LB}$ yang masing-masing berisi logam berat merkuri, kadmium, timbal dan campuran logam berat tembaga, merkuri, kadmium, timbal pada konsentrasi tertentu. Pengukuran dilakukan pada panjang gelombang $600 \mathrm{~nm}$ pada jam-jam yang telah ditentukan hingga mencapai kekeruhan sel tertentu. Kultur bakteri sebanyak $10 \mathrm{ml}$ disentrifugasi pada kecepatan $4.000 \mathrm{rpm}$ selama 60 menit kemudian sel bakteri didestruksi dengan 1 $\mathrm{M} \mathrm{HNO}_{3}$ pada suhu $325^{\circ} \mathrm{C}$. Akumulasi logam berat di dalam sel diukur dengan spektrofotometer serapan atom panjang

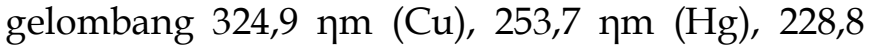
$\eta \mathrm{m}$ (Cd) dan 283,3 $\mathrm{nm}(\mathrm{Pb})$. Pengukuran konsentrasi merkuri dilakukan dengan menggunakan alat Cold Vapor Atomic Fluorescence Spectrometry (CVAFS).

\section{HASIL DAN PEMBAHASAN}

\section{Uji Resistensi Acinetobacter sp. IrC2 Terhadap Berbagai Logam Berat}

Uji multiresistensi Acinetobacter sp. IrC2 terhadap berbagai logam berat merkuri, kadmium, timbal, dan campuran logam berat ditentukan berdasarkan nilai MIC. Tabel 1 menunjukkan bahwa Acinetobacter sp. IrC2 mempunyai sifat multiresistensi terhadap merkuri, kadmium, dan timbal. Konsentrasi minimal yang dapat menghambat pertumbuhan bakteri masingmasing adalah sebesar $12 \mathrm{mM} \mathrm{HgCl}, 8 \mathrm{mM}$ $\mathrm{Cd}\left(\mathrm{NO}_{3}\right)_{2}$ dan $18 \mathrm{mM} \mathrm{Pb}\left(\mathrm{NO}_{3}\right)_{2}$. Bakteri dapat tumbuh dalam campuran logam berat tembaga, merkuri, kadmium, dan timbal dengan nilai MIC sebesar 4,5 mM. Bakteri ini memiliki multiresistensi terhadap beberapa logam berat karena diisolasi dari kawasan industri di Rungkut Surabaya yang banyak menghasilkan limbah berbagai logam berat sehingga sudah teradaptasi dengan lingkungan tercemar (Irawati et al., 2012). Beberapa penelitian sebelumnya juga melaporkan adanya bakteri multiresisten logam berat. Micrococcus luteus merupakan bakteri multiresisten logam berat yaitu resisten terhadap tembaga, kadmium, timbal, nikel, dan seng (Sulaimon et al., 2014). Micrococcus sp. juga dapat mengakumulasi logam berat tersebut khususnya tembaga dan timbal (Puyen et al., 2012).

Baz et al. (2015) mengatakan bahwa tingkat resistensi bakteri tergantung pada tingkat konsentrasi logam berat di habitat dimana bakteri tersebut diisolasi. Penelitian sebelumnya melaporkan bahwa Klebsiella sp., Acinetobacter sp., and Escherichia coli adalah bakteri indigen yang diisolasi dari daerah tercemar. Klebsiella sp. yang diisolasi dari tanah yang tercemar bahan bakar terbukti resisten terhadap kromium, kadmium, dan tembaga (Aransiola et al., 2017). Acinetobacter sp. yang diisolasi dari sungai Aconcagua yang tercemar minyak terbukti resisten terhadap tembaga dan kadmium (Mendez et al., 2017).

Multiresistensi Acinetobacter sp. IrC2 lebih besar dibandingkan dengan 59 isolat bakteri actinobacteria yang diisolasi dari daerah Sidi Bouatman. Isolat actinobacteria ini memiliki sifat multiresistensi terhadap lima jenis logam berat yaitu timbal, tembaga, kadmium, seng, dan kromium. Isolat-isolat bakteri ini memiliki resistensi terhadap timbal dan kromium dengan nilai MIC masing-masing sebesar 0,55 ppm dan 0,15 ppm, serta memiliki resistensi terhadap tembaga, seng, dan kadmium dengan nilai MIC sebesar 0,1 ppm. Pertumbuhan isolat bakteri ini

Tabel 1. Hasil uji minimum inhibitory concentration (MIC).

\begin{tabular}{lc}
\hline \multicolumn{1}{c}{ Logam Berat } & MIC $(\mathrm{mM})$ \\
\hline $\mathrm{Hg}$ & 12 \\
$\mathrm{Cd}$ & 8 \\
$\mathrm{~Pb}$ & 18 \\
Multi Resisten $(\mathrm{Cu}, \mathrm{Hg}, \mathrm{Cd}, \mathrm{Pb})$ & 4,5 \\
\hline
\end{tabular}


mengalami penurunan dengan adanya tembaga, seng, dan kromium (Baz et al., 2015).

\section{Uji Resistensi Acinetobacter sp. IrC2 Terhadap Merkuri}

Hasil uji resistensi menunjukkan bahwa Acinetobacter sp. IrC2 memiliki resistensi yang sangat tinggi terhadap merkuri (Gambar 1) yaitu dapat tumbuh hingga $12 \mathrm{mM} \mathrm{HgCl}_{2}$ atau setara dengan 2.407 ppm. Menurut Hynninen (2010), bakteri yang mampu hidup pada 5 ppm $\mathrm{HgCl}_{2}$ sudah dapat digolongkan sebagai bakteri berketahanan tinggi terhadap merkuri. Acinetobacter sp IrC2 memiliki resistensi yang lebih tinggi dibandingkan genus bakteri lain. Genus Salmonella, Streptococcus pyrogenes, Vagococcus fluvialis serta Escherichia coli resisten hingga 200 ppm $\mathrm{HgCl}_{2}$ sedangkan genus Lampropedia,
Providencia, Serratia, Shigella, Eneterobacter dan Bacillus hanya mampu tumbuh pada $10 \mathrm{ppm}$ $\mathrm{HgCl}_{2}$ (Shakoori \& Muneer, 2002). Genus Enterobacter yang diisolasi dari sungai Baghmati di Kathmandu hanya mampu hidup pada 80 ppm $\mathrm{HgCl}_{2}$ (Hynninen, 2010).

Pengamatan pertumbuhan koloni Acinetobacter sp. IrC2 dalam medium yang mengandung berbagai konsentrasi merkuri menunjukkan bahwa semakin tinggi konsentrasi merkuri maka koloni yang tumbuh semakin sedikit. Hal ini menunjukkan adanya pengaruh toksisitas merkuri pada konsentrasi yang tinggi terhadap pertumbuhan bakteri. Pertumbuhan bakteri pada konsentrasi yang tinggi yaitu $3 \mathrm{mM}$ dan $5 \mathrm{mM}$ menunjukkan tekstur koloni membentuk eksopolimer berupa lendir yang disekresikan dari sel bakteri dan diduga berperan mengikat merkuri

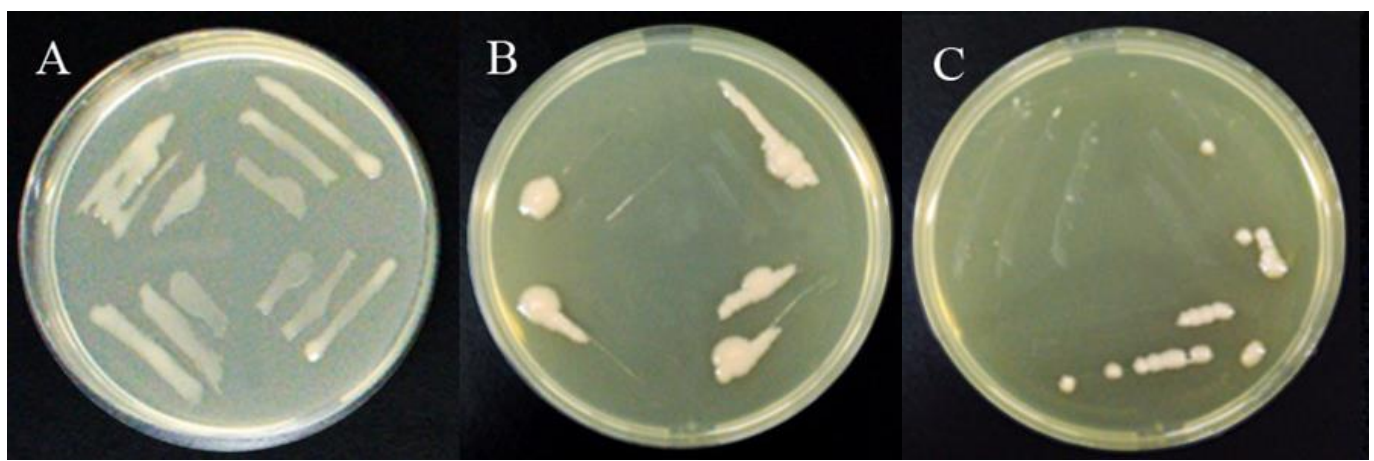

Gambar 1. Pertumbuhan Acinetobacter sp. IrC2 pada medium LB yang mengandung berbagai konsentrasi merkuri. A. 1,5 mM, B. 3 mM, C. $5 \mathrm{mM}$.

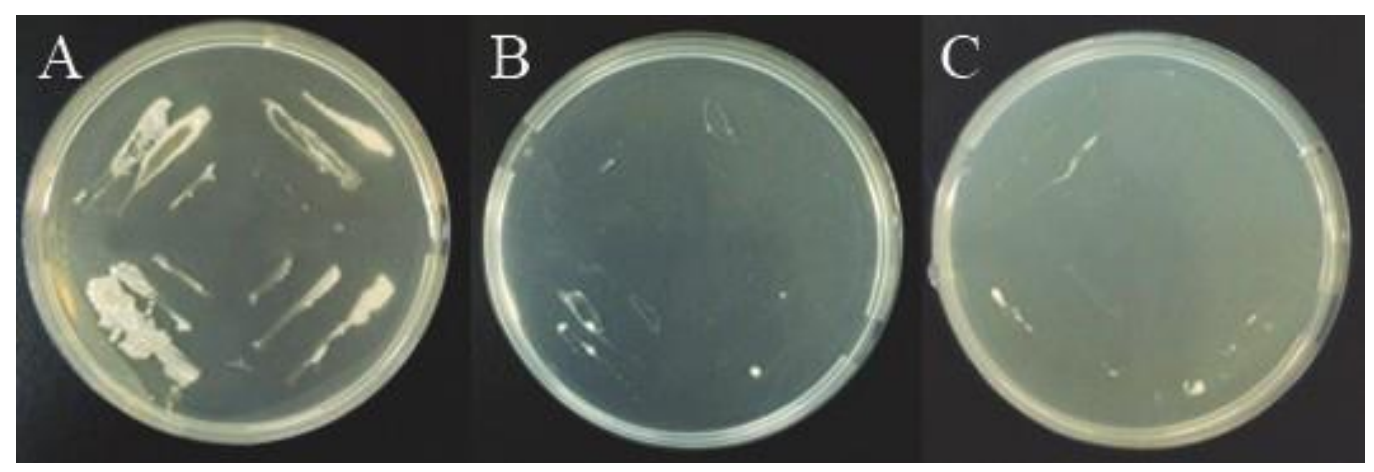

Gambar 2. Pertumbuhan Acinetobacter sp. IrC2 pada medium LB yang mengandung berbagai konsentrasi $\mathrm{CdSO}_{4}$. A. 1,5 mM, B. 2 mM, C. 2,5 mM. 
serta menghalangi merkuri agar tidak memasuki sel. Menurut Pushkar et al. (2015), sekresi eksopolimer merupakan salah satu mekanisme pertahanan diri yang dilakukan bakteri di lingkungan tercemar. Vicentin et al. (2017) mengatakan bahwa adanya logam berat menginduksi produksi eksopolimer beberapa galur bakteri yang berperan untuk mengikat logam berat secara ekstraseluler. Kavamura \& Esposito (2010) melaporkan bahwa beberapa bakteri resisten menghasilkan eksopolimer yang berperan sebagai agen pengikat logam berat sebagai bentuk mekanisme adaptasi dan toleransi untuk menurunkan toksisitas logam berat bagi bakteri.

\section{Uji Resistensi Acinetobacter sp. IrC2 Terhadap Kadmium}

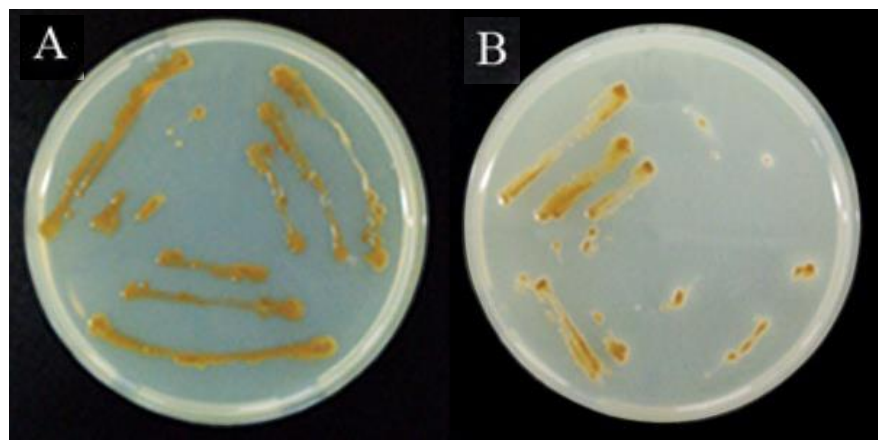

Gambar 3. Pertumbuhan Acinetobacter sp. IrC2 pada medium LB yang mengandung berbagai konsentrasi timbal. A. $8 \mathrm{mM}$, B. $10 \mathrm{mM}$.

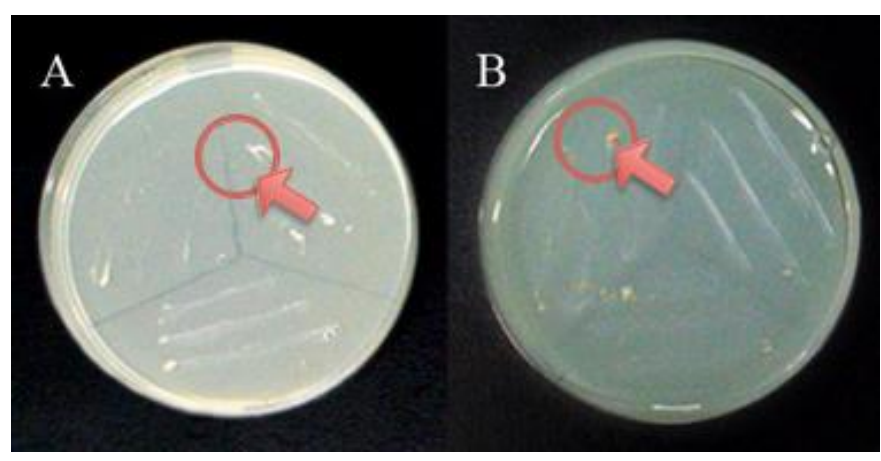

Gambar 4. Pertumbuhan Acinetobacter sp. IrC2 pada medium LB yang mengandung campuran tembaga, merkuri, kadmium, dan timbal. A. 0,5 mM, B. 3,5 mM.
Hasil uji resistensi menunjukkan bahwa Acinetobacter sp. IrC2 memiliki resistensi terhadap kadmium dengan nilai MIC sebesar $8 \mathrm{mM}$ atau setara dengan 890 ppm. Resistensi bakteri ini lebih tinggi dua kali lipat dibandingkan bakteri yang diisolasi oleh Shakoori \& Muneer (2002) yaitu hanya resisten hingga $350 \mathrm{ppm}$. Resitensi bakteri ini juga lebih tinggi dibandingkan dengan $P$. syringae pv. tomato PT23 dan P. putida 08891 yang masing-masing hanya resisten hingga $0.4 \mathrm{mM}$ dan $7 \mathrm{mM} \mathrm{CdSO}$. Gambar 2 menunjukkan pertumbuhan koloni bakteri pada medium yang mengandung berbagai konsentrasi kadmium. Pertumbuhan koloni bakteri semakin sedikit pada konsentrasi kadmium yang tinggi menunjukkan bahwa semakin tinggi konsentrasi kadmium semakin bersifat toksik bagi bakteri. Menurut Hynninen (2010), mekanisme bakteri dalam menanggapi kadmium adalah dengan cara mengakumulasi logam berat tersebut di dalam periplasma dan sitoplasma.

Abbas et al., (2018) mengatakan bahwa bakteri yang dapat bertahan hidup dengan adanya kadmium karena melakukan mekanisme resistensi dengan tiga macam cara, yaitu: 1) mengeluarkan kadmium dari sel, 2) mendetoksifikasi kadmium dengan cara mengubah menjadi bentuk yang kurang toksik, dan 3) mengikat kadmium serta mengakumulasi di dalam sel. Pengeluaran kadmium dari dalam sel dikendalikan oleh gen cadA and cadB yang berperan mengkode protein pompa. Gugus fungsional seperti gugus amina, karboksil, fosfat, hidroksil berperan untuk memfasilitasi pengikatan kadmium di permukaan sel. Bakteri mengekspresikan enzim yang terlibat dalam detoksifikasi kadmium dan membuat agar membran bakteri menjadi impermeable terhadap kadmium.

\section{Uji Resistensi Acinetobacter sp. IrC2 Terhadap Timbal (Pb)}

Hasil uji resistensi menunjukkan bahwa Acinetobacter sp. IrC2 memiliki resistensi yang tinggi terhadap timbal yaitu dengan nilai MIC sebesar $18 \mathrm{mM} \mathrm{Pb}$ atau setara dengan 3.729,6 ppm. Resistensi bakteri ini lebih tinggi 3,5 kali lipat dibandingkan resistensi Eschericia coli dan P. putida 
08891 dengan nilai MIC 5 mM (Spain \& Alm, 2003; Cooksey \& Azad, 1992) dan Vibrio alginolyticus dengan nilai MIC 2,5 mM (Nies, 1999). Resistensi Acinetobacter sp. IrC2 juga lebih tinggi dibandingkan dengan Salmonella, Streptococcus pyrogenes, dan Vagococcus fluvialis dengan nilai MIC masing-masing sebesar 300 ppm dan 400 ppm (Spain \& Alm, 2003).

Gambar 3 menunjukkan bahwa penambahan konsentrasi timbal mengakibatkan terjadinya perubahan warna pada koloni Acinetobacter sp. IrC2 menjadi kecokelatan sebagai mekanisme resistensi. Intensitas warna cokelat semakin meningkat pada konsentrasi timbal yang tinggi. Penampakan koloni bakteri semakin sedikit pada medium yang konsentrasinya tinggi. Terjadinya perubahan warna pada koloni ini diduga disebabkan oleh adanya akumulasi ion ion $\mathrm{Pb}^{2+} \mathrm{ke}$ dalam sel bakteri. Hal serupa terjadi saat Acinetobacter sp. IrC2 ditumbuhkan pada medium yang mengandung $5 \mathrm{mM} \mathrm{CuSO}_{4}$. Bakteri ini juga mengalami perubahan warna menjadi biru karena proses akumulasi tembaga di dalam periplasma, sitoplasma, dan membran sel (Irawati et al., 2012).
Gonzales et al., (2010) mengatakan bahwa eksopolisakarida mengikat ion tembaga dengan interaksi elektrostatik dan memperangkapnya di luar sel. Mekanisme ini merupakan mekanisme yang pasif namun dapat melindungi bakteri secara efektif terhadap toksisitas logam berat.

\section{Uji Resistensi Acinetobacter sp. IrC2 Terhadap Campuran Logam Berat}

Hasil uji resistensi Acinetobacter sp. IrC2 membuktikan bahwa bakteri ini juga resisten terhadap campuran tembaga, merkuri, kadmium, dan timbal dengan nilai MIC sebesar 4,5 mM. Gambar 4 menunjukkan bahwa terjadi perubahan warna koloni bakteri ketika ditumbuhkan pada konsentrasi campuran logam berat yang lebih tinggi. Warna koloni berubah dari putih menjadi kecoklatan mungkin disebabkan adanya proses akumulasi campuran logam berat di dalam sel.

\section{Uji Kemampuan Akumulasi Logam Berat}

Bakteri mengembangkan beberapa mekanisme dalam menghadapi logam berat konsentrasi tinggi, satu diantaranya yang banyak

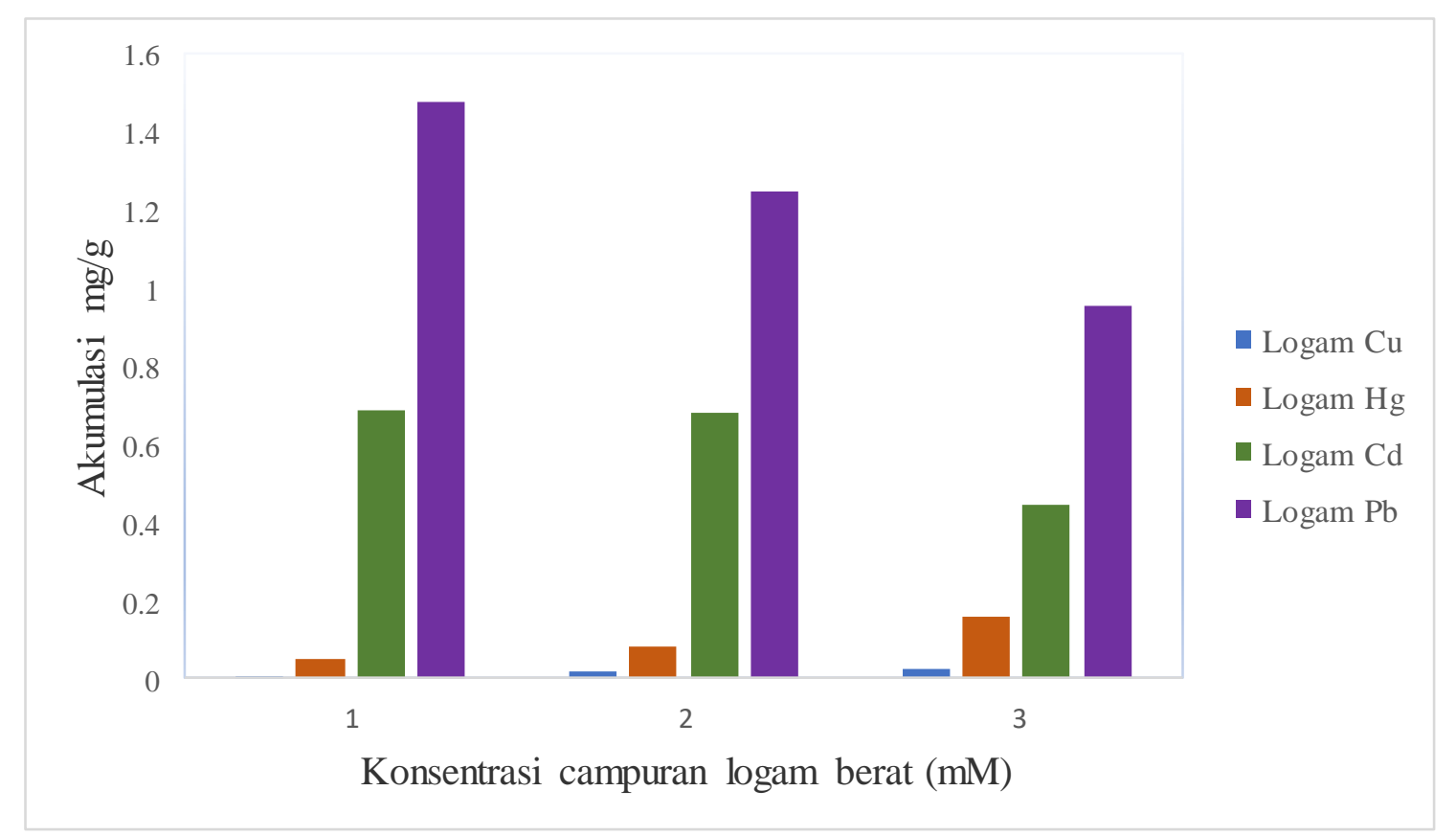

Gambar 5. Uji potensi akumulasi isolat IrC2 pada medium yang mengandung berbagai konsentrasi campuran logam tembaga, merkuri, kadmium, dan timbal. 
dilakukan adalah dengan cara bioakumulasi logam berat. Nies (1999) mengatakan bahwa mekanisme resistensi logam berat adalah dengan cara mengakumulasi ion logam pada dinding sel oleh gugus bermuatan negatif pada dinding sel bakteria yang akan mengikat kation logam melalui mekanisme seperti elektrostatis, gaya van der Waals, ikatan kovalen serta kombinasi ketiga mekanisme tersebut.

Acinetobacter sp. IrC2 pada medium campuran logam berat tembaga, merkuri, kadmium, dan timbal dapat mengakumulasi masing-masing logam berat tersebut (Gambar 5). Acinetobacter sp. IrC2 yang tumbuh pada medium campuran $1 \mathrm{mM}$ tembaga, merkuri, kadmium, dan timbal masing-masing dapat mengakumulasi logam berat tersebut sebesar 0,002 $\mathrm{mg}, 0,047 \mathrm{mg}$, $0,684 \mathrm{mg}, 1,476 \mathrm{mg}$ per gram berat kering sel sedangkan pada konsentrasi campuran $2 \mathrm{mM}$ masing-masing meningkat menjadi $0,017 \mathrm{mg}$, $0,084 \mathrm{mg}, 0,678 \mathrm{mg}$, dan $1,250 \mathrm{mg} / \mathrm{g}$ per gram berat kering sel. Jumlah akumulasi tertinggi terjadi ketika bakteri ditumbuhkan pada campuran $3 \mathrm{mM}$ yaitu masing-masing sebesar 0,023 mg, 0,160 mg, 0,445 mg, dan 0,952 mg per gram berat kering sel.

Jumlah akumulasi tembaga dan merkuri meningkat seiring dengan peningkatan konsentrasi logam berat dalam medium sedangkan jumlah akumulasi kadmium hanya meningkat hingga $2 \mathrm{mM}$ tetapi menurun pada konsentrasi yang tinggi yaitu campuran $3 \mathrm{mM}$. Hal ini menunjukkan bahwa bakteri melakukan mekanisme resistensi yang berbeda terhadap masing-masing logam berat tersebut. Mekanisme resistensi bakteri terhadap tembaga dan merkuri adalah dengan cara akumulasi sedangkan resistensi terhadap kadmium mungkin dilakukan dengan cara lain selain secara akumulasi. Abbas et al. (2018) mengatakan bahwa mekanisme resistensi bakteri terhadap kadmium selain dengan cara akumulasi adalah dengan cara pengeluaran kadium atau perubahan bentuk kadmium menjadi senyawa yang kurang toksik.

Kemampuan akumulasi timbal menurun seiring dengan peningkatan konsentrasi campuran logam berat tersebut dari $1 \mathrm{mM}$ hingga $3 \mathrm{mM}$ menunjukkan bahwa timbal merupakan logam berat yang paling toksik. Mohan et al. (2013) mengatakan bahwa berbagai mekanisme resistensi bakteri yang dilakukan dalam menanggapi toksisitas timbal adalah dengan cara pengeluaran, pengikatan ekstraseluler, biosorpsi, pengendapan, perubahan morfologi sel, peningkatan produksi siderophore pengikat logam berat, serta bioakumulasi intraseluler. Penurunan kemampuan akumulasi bakteri seiring dengan peningkatan konsentrasi timbal menunjukkan bahwa bakteri melakukan mekanisme lain selain mekanisme akumulasi yaitu mungkin dengan cara pengeluaran timbal. Timbal toksik bagi bakteri karena menghambat aktivitas enzim serta merusak DNA dan permeabilitas sel.

Beberapa bakteri dapat menurunkan toksisitas timbal dengan melakukan mekanisme yang melibatkan pengikatan ekstraseluler atau intraseluler, pembentukan eksopolisakarida ekstraseluler, pembentukan protein metallotheionein, pengendapan, dan biomineralisasi (Naik et al., 2012). Beberapa bakteri dapat membentuk senyawa timbal yang tidak larut seperti sulfida, hidroksida, dan karbonat yang dapat menurunkan toksisitas timbal (Park et al., 2011). Beberapa bakteri dapat mengubah $\mathrm{Pb}(\mathrm{II})$ menjadi bentuk mineral yang stabil dan tidak larut sehingga dapat bertahan hidup di daerah yang terkontaminasi timbal seperti yang dilakukan oleh Bacillus thuringiensis 016 (Chen et al., 2015).

\section{KESIMPULAN}

Acinetobacter sp. IrC2 sebagai bakteri resisten temaga terbukti mempunyai sifat multiresistensi yang sangat tinggi terhadap merkuri, kadmium, dan timbal dengan nilai MIC masing-masing adalah sebesar $12 \mathrm{mM}, 8 \mathrm{mM}$ dan $18 \mathrm{mM}$. Bakteri dapat tumbuh dalam campuran logam berat tembaga, merkuri, kadmium, dan timbal dengan nilai MIC sebesar 4,5 mM. Peningkatan konsentrasi logam berat menurunkan densitas koloni yang tumbuh serta membuat koloni bakteri berubah menjadi kecoklatan dan menghasilkan eksopolimer. Mekanisme resistensi bakteri dalam 
menanggapi toksisitas logam berat secara umum adalah dengan cara akumulasi. Jumlah akumulasi terbesar bakteri dalam medium campuran logam berat tembaga, merkuri, kadmium, dan timbal adalah masing-masing sebesar $0,023 \mathrm{mg}, 0,084 \mathrm{mg}$, 0,684 $\mathrm{mg}, 1,476 \mathrm{mg}$ per gram berat kering sel.

Bakteri indigen Indonesia Acinetobacter sp. IrC2 yang resisten terhadap berbagai logam berat dan melakukan mekanisme resistensi dengan cara akumulasi diharapkan dapat bermanfaat untuk pengembangan usaha pengolahan limbah secara biologis di Indonesia. Disarankan agar setiap industri memiliki instalasi pengolahan limbah dan melakukan pengolalahan limbah secara biologis dengan menginokulasikan biakan bakteri ini sehingga terjadi penyisihan logam berat sebelum dibuang ke lingkungan.

\section{DAFTAR PUSTAKA}

Abbas, S.Z., M. Rafatullah, K. Hossain, N. Ismail, H.A. Tajarudin, and H.P.S.A. Khalil. 2018. A review on mechanism and future perspectives of cadmiumresistant bacteria. International Journal of Environmental Science and Technology. 15(1): 243-262.

Aransiola, E.F., O.A. Ige, E.O. Ehinmitola, and S.K. Layokun. 2017. Heavy metals bioremediation potential of Klebsiella species isolated from diesel polluted soil. Afr. J. Biotechnol. 16(19): 1098-1105.

Banvalvi, G. 2011. Cellular effects of heavy metals. Springer. London.

Baz, S.E., M. Baz, M. Barakate, L. Hassani, A.E. Gharmali, and B. Imziln. 2015. Resistance to and accumulation of heavy metals by Actinobacteria isolated from abandoned mining areas. The Scientific World Journal. 2015: 1-14.

Chan, K.G., S. Atkinson, K. Mathee, C.L. Koh, and P. William. 2011. Characterization of N-acylhomoserine lactonedegrading bacteria associated with Zingiber officinale (ginger) rhizosphere: Co-existence of quorum quenching and quorum sensing in Acinetobacter and Burkholderia. BMC Microbiol. 11(1): 51.

Chen, Z., X. Pan, H. Chen, Z. Lin, and X. Guan. 2015. Investigation of lead (II) uptake by Bacillus thuringiensis 016. World J. Microbiol Biotechnol. 31: 1729-1736.

Cooksey, D., and H. Azad. 1992. Accumulation of copper and other metals by cooper-resistant plant-pathogenic and saprophytic pseudomonads. Applied and Environmental Microbiology. 58: 274-278.

Dash, S., H.R. Dash, and J. Chakraborty. 2016. Genetic basis and importance of metal resistant genes in bacteria for bioremediation of contaminated environments with toxic metal pollutants. Appl Microbiol Biotechnol. 100: 29672984.

Gonzales, A.G., L. S. Shirokova, O.S. Pokrovsky, E.E. Emnova, R.E. Martinez, and J.M. Santana-Casiano. 2010. Adsorption of copper on Pseudomonas aerofaciens: protective role of surface exopolysaccharides. J. Colloid Intl Sci. 350: 305-314.

Hynninen, A. 2010. Zinc, cadmium and lead resistance mechanisms in bacteria and their contribution to biosensing. [Disertasi]. University of Helsinki. Finlandia

Irawati, W., T. Yuwono, H. Hartiko, and J. Soedarsono. 2012. Molecular and physiological characterization of copperresistant bacteria isolated from activated sludge in an industrial wastewater treatment plant in RungkutSurabaya, Indonesia. Microbiol J. 3: 107-116.

Irawati, W., N.P. Ompusunggu, D.N. Susilowati, and T. Yuwono. 2019. Molecular and physiological characterization of indigenous copper-resistant bacteria from Cikapundung River, West Java, Indonesia. Biodiversitas. 20(2): 344-349.

Kavamura, V.N., and E. Esposito. 2010. Biotechnological strategies applied to the decontamination of soils polluted with heavy metals. Biotechnol Adv. 28(1): 61-69.

Méndez, V., S. Fuentes, V. Morgante, M. Hernández, M. González, E. Moore, and M. Seeger. 2017. Novel hydrocarbonoclastic metal-tolerant Acinetobacter and Pseudomonas strains from Aconcagua river oil polluted soil. J Soil Sci Plant Nutr. 17(4): 1074-1087.

Mohan, M., N. Santosh, and K. Dubey. 2013. Lead resistant bacteria: Lead resistance mechanisms, their applications in lead bioremediation and biomonitoring. Ecotoxicology and Environmental Safety. 98: 1-7.

Naik, M.M., A. Pandey, and S.K. Dubey. 2012. Pseudomonas aeruginosa strain WI-1 from Mandovi estuary possesses metallothionein to alleviate lead toxicity and promotes plant growth. Ecotoxicol Environ Saf. 79: 129-133.

Nies, D.H. 1999. Microbial heavy metal resistance. Appl. Microbiol Biotechnol. 51: 730-750.

Park, J.H., N. Bolan, M. Megharaj, N. Ravi, and J.W. Chung. 2011. Bacteria assisted immobilization of lead in soils: implications for remediation. Pedologist. 54: 162-174.

Pushkar, B.K., P.I. Sevak, and A. Singh. 2015. Isolation and characterization of potential microbe for bio-remediating heavy metal from Mithi river. Ann Appl Bio-sci. 2(2): 1-27

Puyen, Z.M., E. Villagrasa, J. Maldonado, E. Diestra, I. Esteve, and A. Sole. 2012. Biosorption of lead and copper by heavy-metal tolerant Micrococcus luteus DE2008. Bioresour Technol. 126: 233-237.

Saranraj, P., and D. Stella. 2012. Bioremediation of sugar mill effluent by immobilized bacterial consortium. Intl J. Res Pure Appl Microbiol. 2(4): 43-48.

Shakoori, A., and B. Muneer. 2002. Cooper-resistance bacteria from industrial effluents and their role in remediation of heavy metals in wastewater. Folia Microbiol. 47: 43-50.

Spain, A., and E. Alm. 2003. Implications of microbial heavy metal tolerance in the environment. Undergraduate Research. 2: 1-6. 
Sulaimon, A.M., A.T. Odeyemi, A.A. Ogunjobi, and L.O. Ibrahim. 2014. Bioaccumulation of heavy metals using selected heavy metal tolerant organisms isolated from dumpsite leachate. Nature and Science. 12(10): 101-106.

Vicentin, R.P., J.V. Santos, C.R.G. Labory, A.M. da Costa, F.M.S. Moreira, and E. Alves. 2017. Tolerance to accumulation of cadmium, copper, and zinc by Cupriavidus necator. Rev Bras Cienc Solo. 42: e0170080.

Williams, G.P., M. Gnanadesigan, and S. Ravikumar. 2012. Biosorption and biokinetic studies of halobacterial strains against $\mathrm{Ni2}+, \mathrm{Al} 3+$, and $\mathrm{Hg} 2+$ metal ions. Bioresour Technol. 107: 526-529.

Williams, C.L., H.M. Neu, J.J. Gilbreath, S.L.J. Michel, D.V. Zurawski, and D.S. Merrella. 2016. Copper resistance of the emerging pathogen Acinetobacter baumannii. Appl Environ Microb. 82(20): 6174-6188.

Zaki. S., and S. Farag 2010. Isolation and molecular characterization of some copper biosorped strains. Int J Environ Sci Tech. 7(3): 533-560. 